\title{
PREZYDENCKI LOBBING. REGULACJA PRAWNA DZIAŁALNOŚCI LOBBINGOWEJ W ODNIESIENIU DO PREZYDENTA RP. TEORIA I PRAKTYKA
}

1. Polska ustawa o działalności lobbingowej $\mathrm{w}$ procesie stanowienia prawa z 7 lipca 2005 r. ${ }^{1}$ (zwana dalej udl lub ustawą lobbingową) obchodziła w 2015 roku swoje dziesięciolecie. W momencie uchwalenia była trzecią w Europie (jeżeli zaliczymy do niej Gruzję), po gruzińskiej z 1998 r. i litewskiej z 2000 r. regulacją lobbingową. Ogólnokrajowe, ustawowe regulacje lobbingowe obowiązywały wówczas również na Filipinach (1957 r.), w Kanadzie (1988 r.) i USA (1995 r.). W obu państwach Ameryki Północnej uchwalono także osobne regulacje na poziomie stanowym (prowincjonalnym) i lokalnym.

Chociaż w ciągu minionej dekady proces regulacji lobbingu był na świecie kontynuowany, to przypadki uwieńczenia sukcesem wysiłków projektodawców nie są częste. W 2011 r. w efekcie uznania jej za nieskuteczną doszło do uchylenia węgierskiej ustawy lobbingowej z 2006 r. Do nielicznych państw, w których udało się uchwalić ustawy lobbingowe dołączył w 2007 r. Tajwan, w 2008 r. Macedonia, w 2010 r. Słowenia, w 2011 r. Czarnogóra, w 2012 r. Austria (która była pierwszym krajem Europy zachodniej, w której udało się dokonać tego dzieła), a w 2015 r. Irlandia. Irlandzka regulacja weszła w życie 1 września 2015 r.

Zakres przedmiotowy regulacji lobbingu w większości wymienionych państw jest szeroki i wykracza poza działania adresowane do parlamentu. Adresatem działalności lobbingowej może być także rząd, organy samorządu terytorialnego, a nawet sądy. W ten sposób doszło do wyodrębnienia szczególnych odmian lobbingu - ustawodawczego, wykonawczego, samorządowego czy sądowniczego. Wśród organów podlegających wpływom lobbystów znajdują się także prezydenci, jednak tylko część ustaw lobbingowych na świecie obejmuje swoim zakresem również lobbing adresowany do prezydenta. Większość z tych regulacji obejmuje kontrolą wyłącznie lobbing dotyczący prawodawczej działalności prezydentów. Rzadko mają 
one szerszy zakres przedmiotowy obejmujący również inne obszary aktywności tego organu (np. kreacyjne) $)^{2}$.

Analiza praktyki stosowania polskiej ustawy lobbingowej może prowadzić do konstatacji, że jej zakres obejmuje wyłącznie Sejm, Senat i Radę Ministrów. Tymczasem - co jest główną tezą niniejszego artykułu - zgodnie z treścią ustawy także Prezydent RP, jako naczelny organ władzy publicznej, podlega jej reżimowi (podobnie jak i inne „organy władzy publicznej”, np. organy stanowiące samorządu terytorialnego). Z prowadzeniem ,zawodowej działalności lobbingowej” wiążą się konkretne uprawnienia i obowiązki. Te pierwsze obejmują lobbystów, te drugie - również adresata lobbingu. Podmiot, którego działania zmierzają do wywarcia wpływu na proces stanowienia prawa na etapie prezydenckim, czy z udziałem prezydenta, prowadzący swoją działalność w interesie osoby trzeciej, na podstawie odpłatnej umowy cywilnej, powinien przynajmniej uzyskać wpis do rejestru prowadzonego przez ministra właściwego do spraw administracji. Na Szefa i pracowników Kancelarii Prezydenta ustawa nakłada konkretne obowiązki, przede wszystkim sprawozdawcze, ale także związane z koniecznością uregulowania szczegółowych zasad wykonywania działalności lobbingowej adresowanej do Prezydenta. Blisko 10-letnia praktyka stosowania ustawy w ogóle nie uwzględnia tego faktu. Należy stwierdzić dobitnie że ustawa lobbingowa jest $\mathrm{w}$ opisanej części - martwa.

W niniejszym artykule zamierzam udowodnić zaprezentowaną wyżej tezę o objęciu Prezydenta reżimem ustawy, a także zaprezentować na wybranych przykładach zjawisko lobbingu prezydenckiego - czyli działalności lobbingowej adresowanej do Prezydenta RP, aby wzmocnić postulat niezwłocznego wdrożenia działań zmierzających do realizacji postanowień ustawy pomijanych w praktyce działania administracji prezydenckiej przez minioną dekadę.

2. Zgodnie z art. 2 ust. 1 ustawy lobbingowej „działalnością lobbingową jest każde działanie prowadzone metodami prawnie dozwolonymi zmierzające do wywarcia wpływu na organy władzy publicznej w procesie stanowienia prawa". Ust. 2 i 3 art. 1 precyzują, że zawodową działalnością lobbingową jest zarobkowa działalność lobbingowa prowadzona na rzecz osób trzecich w celu uwzględnienia w procesie stanowienia prawa interesów tych osób, wykonywana przez przedsiębiorcę albo przez osobę fizyczną nie będącą przedsiębiorcą na podstawie umowy cywilnoprawnej. W literaturze naukowej panuje zgodność co do zasadności zaliczenia Prezy-

Najszerszy zakres przedmiotowy regulacji, obejmujący również lobbing adresowany do prezydentów (gubernatorów) i dotyczący na ogół różnych obszarów ich aktywności mają regulacje amerykańskie - federalna i część stanowych. Europejskie ustawy lobbingowe od początku w większości obejmowały lobbing ustawodawczy i wykonawczy, w tym adresowany do prezydenta (ale np. litewska - tylko ten pierwszy). Europejskie regulacje lobbingowe uchwalone po 2005 r., kiedy w krótkim czasie przyjęto kilka ustaw tego typu, zawierały już w większości przepisy dotyczące lobbingu adresowanego do prezydentów. Co ciekawe, nie posiada ich najnowsza w Europie ustawa lobbingowa przyjęta w Irlandii, która weszła w życie we wrześniu 2015 r. Kontroli poddano w niej tylko część lobbingu „wykonawczego” zorientowaną na ministrów. 
Prezydencki lobbing. Regulacja prawna działalności lobbingowej w odniesieniu...

denta do grona „organów władzy publicznej”3. Należy więc uznać, że w rozumieniu ustawy Prezydent, jako organ władzy publicznej może być adresatem działalności lobbingowej, w tym jej szczególnej, zawodowej odmiany, z której prowadzeniem ustawodawca łączy określone uprawnienia i obowiązki po stronie adresata i obsługujących go podmiotów, a także podmiotu wykonującego zawodową działalność lobbingową (zawodowego lobbysty).

Status prawny lobbysty zawodowego wykonującego swoją działalność wyłącznie w odniesieniu do prezydenta nie różni się niczym od pozostałych lobbystów zawodowych, których działania są nakierowanie na wywarcie wpływu na Sejm, Senat, czy Radę Ministrów. Oznacza to, że lobbysta ma obowiązek uzyskać wpis do rejestru podmiotów prowadzących zawodową działalność lobbingową prowadzonego przez ministra właściwego do spraw administracji publicznej (art. $11 \mathrm{udl}$ ). Wpis należy uzyskać przed rozpoczęciem działalności (art. 12 udl), a Prezydentowi lub pracownikowi jego administracji, przed którym się występuje należy doręczyć zaświadczenie lub oświadczenie o uzyskaniu wpisu do rejestru, a także oświadczenie wskazujące podmioty, na rzecz których wykonuje tę działalność. Oba oświadczenia są składane pod rygorem odpowiedzialności karnej za składanie fałszywych zeznań (art. 15 ust. $1 \mathrm{i}$ art. 7 ust. 5a udl). W zamian lobbysta uzyskuje m.in. prawo dostępu do Kancelarii Prezydenta i możliwość wykonywania swojej, zawodowej, działalności lobbingowej na terenie Kancelarii (art. $14 \mathrm{udl}$ ).

Na Kancelarii Prezydenta RP, czyli w rozumieniu ustawy lobbingowej: ,urzędzie obsługującym organ władzy publicznej” spoczywa kilka istotnych obowiązków, poza wymienionymi wyżej, polegającymi na umożliwieniu lobbyście zawodowemu wykonywania jego działalności w siedzibie urzędu (art. 14 ust. 2). Zostały one uregulowane w rozdziale 4 ustawy pt. „Kontrola zawodowej działalności lobbingowej”. W tej części, w odniesieniu do lobbingu adresowanego do Prezydenta RP ustawa lobbingowa jest martwa.

Artykuł 16 ustawy lobbingowej nakłada na organy władzy publicznej obowiązek niezwłocznego udostępniania w Biuletynie Informacji Publicznej informacji o działaniach podejmowanych wobec nich przez podmioty wykonujące zawodową działalność lobbingową, wraz ze wskazaniem oczekiwanego przez te podmioty sposobu rozstrzygnięcia. Art. 18 nakłada na kierowników urzędów dodatkowy obowiązek sporządzania corocznie (do końca lutego), i publikowania w BIP zbiorczego zestawienia działań lobbingowych podejmowanych wobec obsługiwanego przez nich (przez kierowany przez nich urząd) organów władzy publicznej. Ustawa precyzuje w art. 18 ust. 2 jakie szczegółowe informacje musi zawierać coroczna, zbiorcza informacja (określenie spraw, w których zawodowa działalność lobbingowa była

3 Zob. P. Kuczma (red.), Ustawa o działalności lobbingowej w procesie stanowienia prawa. Komentarz, Toruń 2013, s. 33; S. Spurek, Komentarz do art. 1, 2, 18, (w:) Działalność lobbingowa w procesie stanowienia prawa. Komentarz, LEX 2015, M. M. Wiszowaty, Działalność lobbingowa w procesie stanowienia prawa. Ustawa z dnia 7 lipca 2005 r. z komentarzem, Warszawa 2010, s. 99-103. 
podejmowana, wskazanie podmiotów, które tę działalność wykonywały, jej formy, z dookreśleniem czy miały na celu wspieranie czy przeciwdziałanie określonym projektom, wreszcie - określenie wpływu, jaki zawodowy lobbysta wywarł w danej sprawie).

Kierownicy urzędów obsługujących organy władzy publicznej, każdy w zakresie swojego działania, mają ponadto ustawowy obowiązek szczegółowego określenia sposobu postępowania pracowników podległego urzędu z podmiotami wykonującymi zawodową działalność lobbingową oraz z podmiotami wykonującymi bez wpisu do rejestru czynności z zakresu zawodowej działalności lobbingowej, w tym sposób dokumentowania podejmowanych kontaktów (art. 16 ust. 2 udl) 4 . Efektem stwierdzenia, że czynności wchodzące w zakres zawodowej działalności lobbingowej są wykonywane przez podmiot niewpisany do rejestru zawodowych lobbystów jest zgodnie z art. 17 ustawy lobbingowej obowiązek pisemnego zawiadomienia ministra właściwego do spraw administracji w celu nałożenia przez niego kary pieniężnej, o której wspomina art. 19 ustawy w określonej tam wysokości zależnej od stopnia wpływu na określone rozstrzygnięcie organu władzy publicznej. Poza licznymi powodami natury poznawczej ${ }^{5}$, czy związanymi z realizacją zasady transparentności procesu decyzyjnego, bieżąca rejestracja działań wchodzących w zakres zawodowej działalności lobbingowej jest więc istotna również z powodu znaczenia zbieranych $w$ ten sposób danych dla ewentualnego wymiaru kary.

Na zakończenie tej części rozważań warto wspomnieć o jeszcze jednym mankamencie ustawy, który warto byłoby skorygować. Ustęp 3 art. 14 ustanawia obowiązek uregulowania zasad wykonywania zawodowej działalności lobbingowej na terenie Sejmu i Senatu w regulaminach każdej izb (poszerzając tym samym materię regulaminów). Tymczasem, w odniesieniu do innych adresatów lobbingu ustawa w ust. 2 tego samego artykułu nakazuje jedynie kierownikom obsługujących je urzędów zapewnić ,podmiotom wykonującym zawodową działalność lobbingową wpisanym do rejestru dostęp do kierowanego przez siebie urzędu w celu umożliwienia właściwego reprezentowania interesów podmiotów, na rzecz których jest wykonywana ta działalność", co w połączeniu z przywołaną wyżej dyspozycją normy art. 16 ust. 2 ustawy lobbingowej stawia urzędników obsługujących organ władzy publicznej będący adresatem lobbingu w gorszej pozycji. Inaczej niż w przypadku Sejmu

$\mathrm{Na}$ tej podstawie stosowne akty wykonawcze wydały liczne organy należące do szeroko rozumianej administracji rządowej. Tytułem przykładu można wymienić: poszczególne ministerstwa, urzędy wojewódzkie, Wyższy Urząd Górniczy i inne urzędy górnicze, Główny Urząd Miar, Główny Urząd Statystyczny, czy Agencję Bezpieczeństwa Wewnętrznego.

5 Zawarty w opisywanych zarządzeniach katalog przykładowych przejawów „kontaktów lobbystycznych” nie obejmuje wszystkich jego form. Pomimo zastosowania klauzuli „w szczególności” de facto dochodzi do ograniczenia analizy (i sprawozdawczości) zachowań petentów do wskazanych w większości zarządzeń 4 przejawów. Jednym z głównych powodów jest zastosowanie w ustawie wyrazu „kontakt”. Sprowadza to analizę lobbingu wyłącznie do przejawów lobbingu bezpośredniego i czynnego, podczas gdy znane są liczne przejawy lobbingu pośredniego, nie polegającego na nawiązywaniu kontaktu. Ustawowy obowiązek regularnych sprawozdań lobbingowych składanych również przez lobbystów mógłby wpłynąć na zmiany w prawie i poszerzenie zakresu czynności lobbingowych poddanych kontroli. 
i Senatu, które uzyskały uprawnienie do szczegółowego określenia zasad wykonywania działalności lobbingowej na swoim terenie, działania urzędników obsługujących inne organy władzy mają się ograniczać do reagowania na określone działania lobbingowe w celu ich rejestracji, przy jednoczesnym założeniu, że celem urzędników jest ułatwienie lobbystom ich działalności. Warto byłoby poszerzyć dyspozycję zawartą w ustępie 3 i w ten sposób doprowadzić do szczegółowego uregulowania zasad wykonywania zawodowej działalności lobbingowej w siedzibie urzędów obsługujących pozostałe organy władzy publicznej, w tym w Kancelarii Prezydenta RP.

Szczególnym uprawnieniem przysługującym Kancelarii Prezydenta na mocy ustawy lobbingowej jest prawo organizowania wysłuchań publicznych dotyczących projektów rozporządzeń. Do takiego wniosku prowadzi wykładnia art. 9 ust. 1 ustawy lobbingowej, który wymienia rozporządzenia, bez zastrzegania, że mają to być wyłącznie akty pochodzące od Rady Ministrów ${ }^{6}$. Wysłuchanie publiczne nie jest typowo lobbingową instytucją. Mogą w nim wziąć udział nie tylko lobbyści, ale także każda osoba zainteresowana pracami nad danym aktem prawnym, która (w przypadku rozporządzenia) najpóźniej 3 dni przed terminem wysłuchania podanym w Biuletynie Informacji Publicznej zgłosi swoje zainteresowanie. Ustęp 6 art. 9 zawiera delegację ustawową do wydania przez Radę Ministrów rozporządzenia regulującego m.in. tryb przeprowadzenia wysłuchania publicznego dotyczącego projektów rozporządzeń i sposób dokumentowania jego przebiegu? ${ }^{7}$. Przepis ten może wzbudzać wątpliwości interpretacyjne odnośnie do zakresu przedmiotowego takiego rozporządzenia. Na pytanie czy obejmuje on także ewentualne wysłuchania dotyczące projektów rozporządzeń Prezydenta lub Krajowej Rady Radiofonii i Telewizji należy udzielić pozytywnej odpowiedzi, z jednym oczywistym zastrzeżeniem. Przedmiotowe rozporządzenie należy stosować z pominięciem tych jego postanowień, które odnoszą się wyłącznie do Rady Ministrów (np. organizacja wysłuchania łącznie z konferencją uzgodnieniową). $Z$ całą pewnością nie można $\mathrm{z}$ treści art. 9 ust. 6 wyprowadzić uprawnienia dla Prezydenta lub KRRiTV do wydania stosownych, analogicznych rozporządzeń, w których uregulowano by zasady przeprowadzania wysłuchań dotyczących rozporządzeń wydawanych przez te podmioty. Byłoby to niezgodne $\mathrm{z}$ zasadą legalizmu wyrażoną $\mathrm{w}$ art. 7 konstytucji, a także $\mathrm{z}$ art. 92 ust. 1 określającym wymogi formalne dotyczące wydawania rozporządzeń. Aby umożliwić wydanie takich rozporządzeń konieczne byłoby uzupełnienie treści art. 9 ust. 6 udl poprzez poszerzenie podmiotowej części upoważnienia ustawowego

6 Do podobnego wniosku dochodzą: P. Kuczma (red.), (Ustawa o działalności lobbingowej..., op. cit., s. 131) i S. Spurek (Komentarz do art. 9, (w:) Działalność lobbingowa..., op. cit.). Przeciwnego zdania jest I. Wróblewska (Wysłuchanie publiczne w Polsce. Analiza rozwiązań normatywnych na tle praktyki ich stosowania, „Przegląd Sejmowy”, 2012, nr 3 (110), s. 98), która łączy możliwość przeprowadzenia wysłuchania z obowiązkiem publikacji projektów rozporządzeń w Biuletynie Informacji Publicznej. Brak obowiązku nie oznacza jednak zakazu, a ustawa lobbingowa wymaga jedynie poinformowania w BIP o terminie wysłuchania z co najmniej tygodniowym wyprzedzeniem (art. 9 ust. 2).

7 Rozporządzenie Rady Ministrów z 7 lutego 2006 r. w sprawie wysłuchania publicznego dotyczącego projektów rozporządzeń (Dz.U. z dnia 24 lutego 2006 r.). 
do wydania rozporządzeń na temat trybu przeprowadzenia wysłuchania o Prezydenta RP i KRRiTV. Zabieg ten nie wydaje się jednak wskazany. Wystarczy dokonanie odpowiedniego uzupełnienia przepisu art. 9 ustawy lobbingowej w celu jego doprecyzowania. Skłaniają ku temu zarówno fakt, że takie wysłuchania (organizowane przez Prezydenta) dotąd w ogóle się nie odbyły, jak i głosy przedstawicieli doktryny negujące prawo do ich organizowania przez podmioty inne niż Sejm i Rada Ministrów.

Analiza przepisów ustawy o wykonywaniu działalności lobbingowej w procesie stanowienia prawa prowadzi do jednoznacznego wniosku, że regulacja obejmuje swoim zakresem także działania adresowane do Prezydenta RP. W konsekwencji obowiązki, które ustawa nakłada na pracowników, a szczególnie kierownika „urzędu obsługującego organ władzy publicznej” dotyczą także pracowników i szefa Kancelarii Prezydenta. Tymczasem, jak wspomniano, ustawa lobbingowa w części odnoszącej się do Prezydenta RP jest martwa. Praktyka stosowania ustawy nie odnotowała ani jednego przypadku jej zastosowania do działalności lobbingowej adresowanej do Prezydenta. Do tej pory nie wydano aktu regulującego wspomniane zasady postępowania pracowników kancelarii Prezydenta z lobbystami zawodowymi. W BIP nie opublikowano ani jednej rocznej informacji na temat zawodowej działalności lobbingowej adresowanej do Prezydenta. Co istotne, obowiązek realizacji takich obowiązków, jak ustanowienie szczegółowego sposobu postępowania pracowników urzędu z lobbystami zawodowymi, czy publikacja w BIP corocznego sprawozdania na temat działalności lobbingowej adresowanej do Prezydenta nie zależą od faktu odnotowania jakiejkolwiek aktywności lobbystów. Zarówno analiza sformułowań zawartych w ustawie lobbingowej, jak i praktyki jej stosowania przez kierowników urzędów obsługujących organy władzy publicznej pozwala na stwierdzenie, że obowiązek ustawowy polegający na sporządzeniu corocznej informacji należy spełnić również wtedy, kiedy nie doszło do ani jednego kontaktu (działania) lobbingowego. Informacja ogranicza się wówczas do stosownej, skrótowej wzmianki o nieodnotowaniu (braku) przykładów zawodowej działalności lobbingowej w danym roku, ale musi zostać sporządzona i opublikowana w BIP ${ }^{8}$.

Brak corocznych informacji na temat przejawów zawodowej działalności lobbingowej adresowanej do Prezydenta RP sprawia, że nie możemy autorytatywnie odpowiedzieć na pytanie, czy Prezydent RP jest obiektem realnego zainteresowania ze strony lobbystów. Możemy jednak udzielić odpowiedzi hipotetycznej, kierując się z jednej strony wynikami analizy dogmatyczno-prawnej, z drugiej - metodą analizy funkcjonalnej, dotyczącej dotychczasowej aktywności Prezydenta w dziedzinie prawodawstwa. Proces tworzenia prawa to jedyny obszar politycznego procesu de-

8 Zob. np. informacje o działaniach lobbingowych w Ministerstwie Obrony Narodowej za lata: 2006, 2010, 2011, 2012, 2013 i 2014, które stwierdzają, że wobec Ministerstwa nie były podejmowane żadne działania lobbingowe (Działania lobbingowe w MON, http://bip.mon.gov.pl/dzialalnosc-urzedu/artykul/dzialalnosc-lobbingowa/dziaania -lobbingowe-w-mon-10246/ (data dostępu: 19.06.2015 r.). 
cyzyjnego, który został objęty regulacją lobbingową w Polsce. Wyłączono spod jej reżimu inne obszary aktywności prezydenckiej - na czele z polityką nominacyjną (Prezydent RP posiada szerokie uprawnienia kreacyjne), czy realizacją uprawnień tradycyjnych głowy państwa - nadawania orderów, czy udzielania łaski, które poza Polską także są uważane za przedmiot działalności lobbingowej.

Posiadane przez Prezydenta RP szerokie uprawnienia w ramach procesu tworzenia prawa pozwalają na zaliczenie go do pierwszorzędnych adresatów zawodowej działalności lobbingowej. Dotyczy to przede wszystkim, chociaż nie tylko, procesu ustawodawczego, w którym Prezydent posiada prawo inicjatywy ustawodawczej (ograniczone pod względem materii tylko o kwestie należące do wyłącznej inicjatywy Rady Ministrów ${ }^{9}$ ), prawo zgłaszania poprawek w trakcie postępowania ustawodawczego, prawo weta (skierowania ustawy do ponownego rozpatrzenia przez Sejm), a także prawo zainicjowania postępowania przez Trybunałem Konstytucyjnym w sprawie zgodności ustawy z konstytucją - nie tylko po jej wejściu w życie, ale także prewencyjnie. To ostatnie uprawnienie, jak wiadomo, przysługuje tylko Prezydentowi ${ }^{10}$. Istotne uprawnienia Prezydent posiada także w stosunku do umów międzynarodowych. Należy do nich przede wszystkim wyłączne prawo ratyfikacji umowy międzynarodowej (jeżeli wymaga ona ratyfikacji). Prezydent posiada także prawo do odmowy ratyfikacji, nawet jeżeli Sejm i Senat wyraziły zgodę na związanie się przez Rzeczpospolitą daną umową międzynarodową. Podobnie jak w przypadku ustaw, Prezydent ma także możliwość odesłania umowy do Trybunału Konstytucyjnego w celu zbadania jej konstytucyjności. Uprawnienia Prezydenta w stosunku do konstytucji obejmują przede wszystkim możliwość zainicjowania postępowania ustawodawczego w sprawie jej zmiany w drodze wniesienia na mocy art. 235 ust. 1 projektu ustawy o zmianie konstytucji. W zgodnej opinii doktryny prawa konstytucyjnego Prezydentowi nie przysługuje prawo weta w stosunku do ustawy o zmianie konstytucji (chociaż kwestia ta budzi wątpliwości) ${ }^{11}$. Dążenie do zawetowania przez Prezydenta ustawy o zmianie konstytucji z jednoczesną prezentacją argumentów na poparcie jego stanowiska i przeciwko odrzuceniu jego weta stanowiłyby typowe

Zgodnie z art. 221 Konstytucji RP Radzie Ministrów przysługuje wyłączne prawo inicjatywy ustawodawczej w zakresie ustawy budżetowej, ustawy o prowizorium budżetowym, zmiany ustawy budżetowej, ustawy o zaciąganiu długu publicznego oraz ustawy o udzielaniu gwarancji finansowych przez państwo.

10 Dla ścisłości dodajmy, że na mocy art. 131 Konstytucji RP także zastępującym Prezydenta RP: Marszałkow Sejmu lub Marszałkowi Senatu.

11 Zob. P. Winczorek, Komentarz do Konstytucji Rzeczypospolitej Polskiej z dnia 2 kwietnia 1997 roku, Warszawa 2008, s. 447; B. Banaszak, Konstytucja Rzeczypospolitej Polskiej. Komentarz, Warszawa 2009, s. 1002; W. Skrzydło, Konstytucja Rzeczypospolitej Polskiej. Komentarz, Kraków 2000, s. 321. Moim zdaniem kwestia ta jest dyskusyjna. Z jednej strony ustrojodawca nie pozbawił Prezydenta tego uprawnienia (tak jak uczynił to expressis verbis w przypadku ustawy budżetowej w art. 224 ust. 1 konstytucji), a więc można by uznać, że Prezydent posiada prawo weta wobec ustawy o zmianie konstytucji, jako odmiany ustawy, na podstawie art. 122 ust. 5 . Z drugiej strony - ewentualna decyzja w sprawie weta byłaby podejmowana wyłącznie przez Sejm większością 3/5 głosów, a więc niższą niż wymagana dla przegłosowania ustawy konstytucyjnej w Sejmie (art. 235 ust. 4 wskazuje większość $2 / 3$ głosów). Nie jest to jednak fakt przesądzający, skoro Sejm musiałby ponownie przegłosować ustawę o zmianie konstytucji i to większością kwalifikowaną. Wynik takiego głosowania nie byłby przesądzony pomimo łatwiejszego (nadal utrudnionego) trybu, szczególnie w świetle argumentów zaprezentowanych przez Prezydenta. 
przejawy działalności lobbingowej w imieniu klienta, któremu zależałoby na zablokowaniu zmian w ustawie zasadniczej. Zawieszające weto prezydenckie w stosunku do zmian konstytucji można by wręcz uznać za przejaw realizacji funkcji Prezydenta określonych w art. 126 konstytucji.

Prezydenckie prawo do wydawania rozporządzeń wykonawczych ma z pewnością mniejsze znaczenie dla zawodowych lobbystów, ale także na tym obszarze można oczekiwać ich aktywności, jeżeli rozporządzenie miałoby wpływ na sytuację prawną zleceniodawcy lobbingu. Jeszcze mniejsze znaczenie dla bieżącej działalności lobbingowej mają prezydenckie rozporządzenia z mocą ustawą. Z jednej strony, za sprawą materii regulacyjnej mogłyby mieć istotny wpływ na sytuację prawną, czy interes licznych podmiotów i grup interesu. $Z$ drugiej strony - ze względu na fakt, że mogą być wydawane tylko w czasie stanu wojennego, po spełnieniu dodatkowych wymogów określonych w art. 234 Konstytucji, nie mają żadnego realnego znaczenia w bieżącej działalności lobbingowej. Wśród uprawnień Prezydenta, które mogą stanowić obiekt zainteresowania lobbystów wymienić należy jeszcze uprawnienia dotyczące referendów ogólnokrajowych. W przypadku referendum dotyczącego zatwierdzenia zmian w konstytucji uchwalonych przez Sejm i Senat i dotyczących rozdziału I, II i XII, inicjatywa Prezydenta doprowadzi do zarządzenia głosowania powszechnego przez Marszałka Sejmu. W sprawach o istotnym znaczeniu dla Państwa Prezydent może nie tylko zainicjować, ale także zarząazić referendum, pod warunkiem uzyskania zgody Senatu RP. Skutkiem wiążącego i rozstrzygającego rezultatu drugiego z wymienionych referendów może być zainicjowanie zmian lub uzupełnień obowiązującego prawa, również przez samego Prezydenta, w celu realizacji woli Narodu. Referendum może być środkiem służącym pośrednio realizacji interesów określonych grup społecznych (grup interesu). Instytucja referendum konstytucyjnego może być wykorzystywana dla zablokowania niepożądanych przez zleceniodawcę lobbingu zmian w Konstytucji. Nie jest to środek, którym łatwo się posłużyć, ale nakłanianie Prezydenta do przeprowadzenia referendów lub przeciwdziałanie takiej decyzji także należałoby zaliczyć do przejawów działalności lobbingowej oraz wykazać w informacji bieżącej i rocznej na temat tej działalności.

Na marginesie należy wspomnieć, że wymienione, potencjalne przykłady działalności lobbingowej adresowanej do Prezydenta będą uznane za spełniające przesłanki działalności zawodowej i jako takie będą podlegały ujawnieniu, wyłącznie jeżeli będzie to działalność zarobkowa, prowadzona na rzecz osób trzecich, na podstawie umowy cywilnoprawnej. Sprawia to, że większość działań posiadających wszystkie typowe cechy działalności lobbingowej (zmierzanie, za wynagrodzeniem i legalnie, do wywarcia wpływu na działania organów władzy publicznej w procesie stanowienia prawa) nie podlega postanowieniom polskiej ustawy lobbingowej ponieważ nie spełnia jednej z przesłanek dotyczących formy prowadzonej działalności. Aktywność etatowego pracownika lub osoby wykonującej swoje działania nieodpłatnie - pomimo ewidentnie lobbystycznego charakteru - nie będzie uznana za zawo- 
Prezydencki lobbing. Regulacja prawna działalności lobbingowej w odniesieniu...

dową działalność lobbingową w rozumieniu polskiej ustawy i jako taka nie podlega ujawnieniu w informacjach bieżących i rocznych sporządzanych przez kierownika urzędu obsługującego organ władzy oraz jego pracowników. To jedna z najpoważniejszych, chociaż nie jedyna wada polskiej ustawy lobbingowej, przesądzająca o jej fasadowym charakterze ze względu na łatwość ominięcia jej postanowień.

3. Dopiero analiza aktywności Prezydenta RP w opisanych kwestiach pozwala na dostrzeżenie realnego zjawiska lobbingu ,prezydenckiego" w Polsce, a także jego potencjalnej skali. Zakres przeprowadzonych badań został ograniczony do kadencji Prezydenta Bronisława Komorowskiego oraz do kilku wybranych uprawnień, jakimi dysponuje polski Prezydent. 5-letni okres jest wystarczający dla ukazania charakterystycznych zjawisk i prawidłowości w opisywanym obszarze procesu decyzyjnego. $\mathrm{Z}$ powodu bierności zobowiązanych do działania podmiotów ten wycinek działalności lobbingowej w Polsce pozostaje poza kontrolą i jawnością, wbrew ustawie lobbingowej obowiązującej w Polsce od prawie 10 lat. Jak stwierdzono, że względu na brak corocznych oficjalnych informacji na temat przejawów zawodowej działalności lobbingowej adresowanej do Prezydenta, poniższe przykłady mają charakter głównie hipotetyczny i wynikają z analizy ogólnie dostępnych danych. Ich wskazanie ma na celu zasygnalizowanie realnego problemu, jakim jest wciąż niepełne obowiązywanie ustawy lobbingowej (która i bez tego ma charakter szczątkowy), decydujące o jej fasadowym charakterze. Przytoczone przykłady mają częściowo wypełnić lukę w wiedzy na temat prezydenckiego lobbingu w Polsce, powstałą z jednej strony z powodu niestosowania ustawy przez zobowiązane do tego podmioty, z drugiej - za sprawą wadliwej, zawężającej definicji lobbingu zawodowego.

Jak wynika z informacji statystycznych podanych na stronie internetowej Prezydenta RP (dane z 2014 r.) w mijającej kadencji prezydent zgłosił 20 projektów ustaw. Liczba ta po jej weryfikacji w oparciu o dane opublikowane na witrynie Sejmu RP urasta do blisko 30 , w tym znajdują się 2 projekty ustawy o zmianie konstytucji. Zagadnienia poruszane w prezydenckich propozycjach nowych ustaw lub nowelizacji były bardzo zróżnicowane i dotyczyły zarówno dziedzin związanych bezpośrednio lub pośrednio z funkcją Prezydenta (jak: siły zbrojne, władza sądownicza, ordery i odznaczenia), jak i takich, których związki z instytucją Prezydenta są luźne lub wręcz trudno je wskazać (prawo wyborcze, prawo pracy, zagospodarowanie przestrzenne, cmentarze i chowanie zmarłych, prawo wodne, stowarzyszenia, zgromadzenia, nasiennictwo, prawo podatkowe, prawo wodne, emerytury i renty).

Analiza treści uzasadnień prezydenckich projektów ustaw nie pozwala na jednoznaczne stwierdzenie czy powstawały one pod wpływem lobbystów. Co istotne, w uzasadnieniach bardzo rzadko pojawiają się jakiekolwiek wzmianki dotyczące genezy projektu - źródeł inspiracji, czy wprost o jego pochodzeniu od konkretnych środowisk, czy osób. Dominują sformułowania ogólne. Należy w tym miejscu uczynić dwa zastrzeżenia. Po pierwsze - w kilku uzasadnieniach pojawiły się odwołania 
do poglądów doktryny, sugestii zawartych w orzecznictwie lub rekomendacji takich podmiotów jak Rada Europy, Bank Światowy, czy uznane instytuty badawcze, jako źródeł inspiracji proponowanych zmian ${ }^{12}$. Są to jednak przypadki rzadkie i na ogół bardzo ogólne odwołania, bez wskazania konkretnych nazwisk i pozycji lub sygnatur orzeczeń. Po drugie - ustawa lobbingowa tylko na Radę Ministrów nakłada obowiązki wynikające z zasady jawności działalności lobbingowej, w szczególności publikowania projektów aktów prawnych w BIP wraz ze wszelkimi dokumentami dotyczącymi prac nad projektem (art. 6 udl). Prezydent (Kancelaria Prezydenta) nie mają więc obowiązku publikowania projektów, czy innych dokumentów w BIP przed ich wniesieniem do Sejmu lub przyjęciem. To kolejny poważny mankament ustawy, który należy pilnie skorygować obejmując zasadą jawności działalności lobbingowej wszystkie organy wyposażone w prawo inicjatywy ustawodawczej oraz prawo wydawania rozporządzeń. Nieliczne przypadki, w których do projektu prezydenckiego dołączono skany pism stanowiących odpowiedź konsultowanych podmiotów dotyczącą konkretnego projektu - wynikają z regulacji ustawowych, które nakładają na projektodawców obowiązek poddania konsultacji projekt aktu prawnego przez podmioty zainteresowane w przypadku, kiedy dotyczy on ich zakresu działania $^{13}$.

W treści niektórych uzasadnień do prezydenckich projektów ustaw można doszukać się wskazówek, które sugerują, że mógł mieć miejsce zewnętrzny wpływ na ich powstanie, konkretne postanowienia lub później na ich modyfikację, przed skierowaniem do Sejmu. Wiedzę tę uzupełniają doniesienia prasowe, które w kilku przypadkach sugerowały co najmniej zainteresowanie określonych grup interesów niektórymi projektami. Wśród projektów prezydenckich jedynie część dotyczy kwestii znajdujących się w obszarze zainteresowań podmiotów prywatnych (przedsiębiorców). Są też takie, które realizują postulaty określonych środowisk (np. samorządowców, polityków), czy grup społecznych. W uzasadnieniach co do zasady pomija się informacje na temat źródeł inspiracji, z których czerpali autorzy określonych projektów, czy powodów które przesądzily o zajęciu się przez Kancelarię Prezydenta określoną sprawą. Czasami pojawiają się na ten temat jedynie szczątkowe wzmianki.

Przechodząc do szczegółowej analizy - z uzasadnienia projektu ustawy o zmianie ustawy - Kodeks pracy oraz niektórych innych ustaw, który wpłynął do Sejmu obecnej kadencji w kwietniu br. możemy dowiedzieć się, że został on skierowany do konsultacji. W ich wyniku 10 podmiotów wymienionych w uzasadnieniu z nazwy

12 Zob. np. przedstawiony przez Prezydenta Rzeczypospolitej Polskiej projekt ustawy o zmianie ustawy - Prawo o postępowaniu przed sądami administracyjnymi (Sejm VII kadencji, Druk nr 1633 z 10.7.2013 r.), uzasadnienie s. $1,15,16,21$ waniu przed sądami administracyjnymi (druk 1633, Uzasadnienie, s. 62-69). 
Prezydencki lobbing. Regulacja prawna działalności lobbingowej w odniesieniu...

zgłosiło uwagi do projektu ${ }^{14}$. Nie podano ani treści tych uwag, ani czy zostały one uwzględnione.

W uzasadnieniu projektu o zmianie niektórych ustaw w związku ze wspieraniem innowacyjności z marca 2015 r. mówi się wprost o zewnętrznej inspiracji dla powstania projektu ustawy. Z ogólnej informacji wynika, że ,potrzebę budowania konkurencyjnej gospodarki opartej na wiedzy i innowacjach dostrzegły [...] organizacje pracodawców, przedstawiając ten problem Prezydentowi RP już w 2010 r. w liście najpilniejszych spraw gospodarczych”. Nie podano jednak żadnych szczegółów dotyczących tych organizacji i ich szczegółowych propozycji. W uzasadnieniu jest także mowa o wynikach różnych badań przeprowadzonych w kraju i zagranicą oraz o rekomendacjach (m.in. Banku Światowego i Komisji Europejskiej). Co szczególnie istotne dla problematyki lobbingu prezydenckiego, w treści uzasadnienia wprost stwierdzono, że do opracowania projektu ustawy doprowadziły mające miejsce w Kancelarii Prezydenta RP w latach 2011-2014 posiedzenia i panele eksperckie Forum Debaty Publicznej „Gospodarka konkurencyjnej Polski”.

Podana informacja zwraca uwagę na interesującą i bez wątpienia cenną inicjatywę Prezydenta RP polegającą na zorganizowaniu cyklu spotkań dotyczących różnych istotnych dla państwa kwestii. Cykl ten pod zbiorczą nazwą „,Forum Debaty Publicznej" miał charakter stałego ciała konsultacyjnego. Kolejne spotkanie Forum, których zorganizowano ponad 60, były okazją do wymiany poglądów przez ekspertów z różnych dziedzin, ale również szansą na prezentację opinii przez przedstawicieli licznych grup interesów wywodzących się z różnych środowisk - samorządowych, naukowych, biznesowych, rządowych czy społecznych. Uczestnicy Forum mieli możliwość bezpośredniego lub pośredniego (poprzez pracowników Kancelarii i doradców) wpływania na kształt prezydenckich inicjatyw ustawodawczych. Zamknięta formuła udziału w Forum - na zaproszenie Prezydenta, dobór większości uczestników według klucza merytorycznego, czy fakt zapraszania przedstawicieli różnych środowisk, w tym naukowców, nie pozbawia Forum częściowo lobbingowego charakteru.

Inną inicjatywą o charakterze eksperckim było „Laboratorium Idei”. Jak informuje strona internetowa Prezydenta RP „Misją Laboratorium Idei - Prezydenckiego Programu Eksperckiego jest [...] wsparcie eksperckie Kancelarii Prezydenta RP w pracy na rzecz modernizacji kraju i kreowania debaty publicznej"16. Laboratorium było programem skierowanym do naukowców, którzy zgodnie z zaproszeniem mieli w ramach Laboratorium realizować własne programy badawcze z możliwością wdrażania ich wyników z udziałem Prezydenta. Analiza zgłaszanych

\footnotetext{
14 Przedstawiony przez Prezydenta Rzeczypospolitej Polskiej projekt ustawy o zmianie ustawy - Kodeks pracy oraz niektórych innych ustaw (Sejm VII kadencji, Druk nr 3288 z 27.3.2015 r.), s. 45.

15 Przedstawiony przez Prezydenta Rzeczypospolitej Polskiej projekt ustawy o zmianie niektórych ustaw w związku ze wspieraniem innowacyjności (Sejm VII kadencji, Druk nr 3286 z 13.3.2015 r.), uzasadnienie s. 1-2.

16 Laboratorium Idei: o programie, http://www.prezydent.pl/kancelaria/laboratorium-idei/o-programie/ (data dostępu: 19.06.2015 r.).
} 
projektów pokazuje, że oprócz zagadnień stricte naukowych pojawiały się liczne propozycje przewidujące konkretne zmiany w obowiązującym systemie prawnym. Zgodnie z zasadami naboru do I edycji programu, z wybranymi osobami zawierano umowy na okres 12 miesięcy w dwóch terminach: począwszy od 1 marca 2012 lub 1 lipca 2012 roku. Od ekspertów wymagana była stała obecność w Kancelarii Prezydenta RP w wymiarze 3 dni w tygodniu oraz udział w cyklicznych spotkaniach zespołu przez cały okres trwania programu eksperckiego. Efektem końcowym rocznego projektu miało być opracowanie „Projektu końcowego” który powinien zawierać koncepcję modernizacji kraju w jednym $\mathrm{z}$ obszarów priorytetowych, wraz ze szczegółowym opisem implementacji proponowanych rozwiązań (aplikacja praktyczna) ${ }^{17}$. Poza niewątpliwą wartością merytoryczną Laboratorium stanowiło potencjalnie kolejną furtkę w dostępie do procesu decyzyjnego Prezydenta, nie poddaną kontroli lobbingowej. O ile w obecnym stanie prawnym trudno byłoby zakwalifikować uczestnika programu do kategorii zawodowych lobbystów, nie byłoby to jednak niemożliwe, o ile poza zatrudnieniem w Kancelarii Prezydenta, łączyłaby go umowa cywilna ze zleceniodawcą działalności lobbingowej. Programy eksperckie powinny zawierać stosowne klauzule eliminujące możliwość naboru do podobnego programu osób powiązanych z grupami interesów (w dalszej perspektywie pożądanych zmian ustawy lobbingowej - należy dodać, że chodzi o jakiekolwiek powiązania, nie tylko na mocy odpłatnej umowy cywilnoprawnej).

Uzasadnienie do projektu nowelizacji „krajobrazowej”, czyli ustawy o zmianie niektórych ustaw w związku ze wzmocnieniem narzędzi ochrony krajobrazu można uznać za najlepsze pod względem merytorycznym lub co najmniej jedno z najlepszych wśród wszystkich uzasadnień projektów prezydenckich minionej kadencji. Zawiera szeroką argumentację z przywołaniem literatury naukowej oraz ekspertyz sporządzanych na zlecenie organów państwa. Dzięki temu pozwala na lepsze poznanie intencji projektodawcy i źródel jego inspiracji. Projekt poddano szerokim konsultacjom. Uzasadnienie wylicza nazwy podmiotów, reprezentujących stronę rządową i społeczną, którym przesłano projekt do konsultacji. Nie załączono jednak skanów odpowiedzi z opiniami konsultowanych podmiotów, ani nie wskazano czy i które sugestie zostały uwzględnione. Jak wynika z uzasadnienia, projekt był udostępniony w internecie przez $30 \mathrm{dni}$. Kolejne zdanie budzi jednak uzasadnione wątpliwości: ,uwagi, które wpłynęły do Kancelarii Prezydenta RP zostały przeanalizowane i częściowo uwzględnione. Odbyło się również spotkanie uzgadniające z organizacjami społecznymi i gospodarczymi" ${ }^{18}$. Poza tą enigmatyczną wzmianką nie podano żadnych informacji dotyczących tego, kogo zaproszono na wspomniane

\footnotetext{
17 Zasady aplikacji w ramach Prezydenckiego Programu Eksperckiego, http://www.prezydent.pl/download/gfx/prezydent/pl/defaultaktualnosci/3084/1/1/zalacznik_nr_1_zasady_aplikacji_w_prezydenckim_programie_eksperckim_final.rtf (data dostępu: 19.6.2015 r.).

18 Przēdstawiony przez Prezydenta Rzeczypospolitej Polskiej projekt ustawy o zmianie niektórych ustaw w związku ze wzmocnieniem narzędzi ochrony krajobrazu. (Sejm VII kadencji, Druk nr 1525 z 28.6.2013 r.). Uzasadnienie s. $35-36$.
} 
spotkanie, ani które uwagi i dlaczego uwzględniono. W ocenie skutków regulacji nie wskazano wszystkich konsekwencji, które może przynieść uchwalenie ustawy. Wśród nich znalazły się znaczące zmiany na rynku reklam wielkoformatowych w Polsce na korzyść jednych i niekorzyść innych jego uczestników - o czym wspominały media, ale milczało uzasadnienie ${ }^{19}$. W projekcie po raz kolejny pojawia się wzmianka o Forum Debaty Publicznej, na którym omawiano zagadnienia, których dotyczy projekt ${ }^{20}$.

Przedstawionej charakterystyce odpowiada uzasadnienie projektu ustawy o współdziałaniu w samorządzie terytorialnym na rzecz rozwoju lokalnego i regionalnego oraz o zmianie niektórych ustaw z 2013 r. Projekt bardzo szerokiej i szczegółowej nowelizacji 40 ustaw został szczegółowo scharakteryzowany i uzasadniony z przywołaniem tez z literatury przedmiotu, a także wyników badań opinii społecznej. Fakt poddania go szerokim konsultacjom został odnotowany w uzasadnieniu. Co istotne - o czym wspomniano w uzasadnieniu i co różni ten projekt od pozostałych $^{21}$ - na stronie internetowej Prezydenta RP przedstawiono szczegółowe sprawozdanie $\mathrm{z}$ dyskusji na temat projektu przeprowadzonych w ramach Forum Debaty Publicznej, a także - na ponad 100 stronach - zestawienie uwag zgłoszonych do projektu za pośrednictwem internetu i listownie. W ramach publicznych konsultacji każda zainteresowana osoba mogła zgłosić swoje opinie, komentarze i propozycje zmian w projekcie ${ }^{22}$. Pozytywną ocenę zastosowanej praktyki obniża fakt, że zarówno sprawozdanie z przeprowadzonych konsultacji społecznych, jak i zestawienie zgłoszonych uwag dostępne na stronie internetowej dotyczy jednego z etapów kilkuletnich prac i prezentuje stan z marca $2011 \mathrm{r}^{23}$, podczas gdy projekt ustawy w ostatecznej wersji został wniesiony do Sejmu w sierpniu 2013 r. Jak wynika z informacji zawartej na stronie internetowej, konsultacje trwały do lutego 2013 r. $^{24}$

19 Jak podano w tygodniku „Wprost” - regulacja „wzburzyła środowiska reklamowe”, a w segmencie billboardów, który może być największym beneficjentem zawartego w ustawie ograniczenia możliwości wywieszania na budynkach reklam wielkoformatowych, jest należąca do Agory S.A. spółka AMS (C. Bielakowski, Wojna ze szmatami, „Wprost”, 13-19 kwietnia 2015 r., s. 20-21).

20 Przedstawiony przez Prezydenta Rzeczypospolitej Polskiej projekt ustawy..., Sejm VII kadencji, Druk 1525, Uzasadnienie, s. 7.

21 Przedstawiony przez Prezydenta Rzeczypospolitej Polskiej projekt ustawy o współdziałaniu w samorządzie terytorialnym na rzecz rozwoju lokalnego i regionalnego oraz o zmianie niektórych ustaw (Sejm VII kadencji, Druk nr 1699 z 30.8.2013 r.). Uzasadnienie s. 39.

22 Forum Debaty Publicznej: Projekt ustawy o samorządzie, marzec 2011 - grudzień 2012, http://www.prezydent. $\mathrm{pl} / \mathrm{dialog} / \mathrm{fdp} / \mathrm{samorzad}$-terytorialny-dla-polski/inicjatywy-ustawodawcze/projekt-ustawy-o-samorzadzie/ (data dostępu: 21.6.2015 r.).

23 Zob. Sprawozdanie z przebiegu konsultacji społecznych dotyczących projektu ustawy o wzmocnieniu udziału mieszkańców w działaniach samorządu terytorialnego, o współdziałaniu gmin, powiatów i województw oraz o zmianie niektórych ustaw w okresie od marca do lipca 2011, Warszawa, lipiec 2011, http://www.prezydent. $\mathrm{pl} /$ download/gfx/prezydent/pl/defaultopisy/2373/2/1/konsultacje_spoleczne_sprawozdanie_lipiec_2011.pdf oraz: Zestawienie uwag do projektu ustawy o wzmocnieniu udziału mieszkańców w samorządzie terytorialnym, współdziałaniu gmin, powiatów i województw oraz o zmianie niektórych ustaw (wersja z dnia 25 marca 2011 roku) http:// www.prezydent.pl/download/gfx/prezydent/pl/defaultopisy/2373/2/1/zalacznik 1.pdf (data dostępu: 21.6.2015 r.). Forum Debaty Publicznej: Projekt ustawy o samorządzie - grudzień 2012 r., http://www.prezydent.pl/dialog/fdp/samorzad-terytorialny-dla-polski/inicjatywy-ustawodawcze/projekt-ustawy-o-samorzadzie/) (data dostępu: 21.06.2015 r.). 
Przykładem zagadnienia, które wzbudziło szerokie zainteresowanie społeczne, polityczne, ale także wpływowych grup interesu były prace nad regulacją prawną dotyczącą żywności modyfikowanej genetycznie (GMO). Prezydent, który w 2011 r. zawetował wniesioną przez rząd ustawę o nasiennictwie, w 2012 r. złożył kolejny projekt ustawy na ten temat. W trakcie stosunkowo szybkich prac ustawodawczych do ustawy wprowadzono m.in. przepisy umożliwiające obrót nasionami GMO. Prezydent ustawę podpisał pomimo szerokiej i burzliwej publicznej dyskusji na ten temat i licznych głosów osób, które apelowały o kolejne weto. Nie jest znany wpływ lobbystów reprezentujących firmy zajmujące się produkcją i obrotem nasionami modyfikowanymi genetycznie na treść ustawy, aktów wykonawczych i decyzję Prezydenta dotyczącą wniesienia ustawy w zaproponowanym brzmieniu. W uzasadnieniu do ustawy z 2012 r. przywołano ustalenia dokonane przez rząd na potrzeby projektu z 2011 r., w tym wyniki szerokich konsultacji, również z prywatnymi grupami interesów (np. organizacjami zrzeszającymi producentów nasion). Brak jest informacji na temat udziału lobbystów w pracach nad nową ustawą. $Z$ doniesień medialnych można wywnioskować, że w Kancelarii Prezydenta odbyły się spotkania z ekspertami i reprezentantami środowisk zainteresowanych tą tematyką ${ }^{25}$.

Na zakończenie tej części rozważań warto przywołać ciekawy przykład projektu ustawy o zmianie ustawy o ochronie gruntów rolnych i leśnych, który zgodnie $\mathrm{z}$ treścią uzasadnienia nie został w ogóle poddany konsultacjom społecznym, ponieważ ich „Przeprowadzenie wiązałoby się ze znacznym opóźnieniem we wniesieniu projektu do Sejmu, a to mogłoby wiązać się z niemożliwością uchwalenia ustawy jeszcze w tej kadencji parlamentu"26. Wniesienie projektu było konsekwencją zawetowania poprzedniej ustawy nowelizującej ustawę o ochronie gruntów rolnych i leśnych w 2014 r. Wobec jego nieodrzucenia przez Sejm Prezydent skutecznie zablokował możliwość odrolnienia gruntów rolnych najwyższych klas decyzją władz samorządowych, a nie ministra. Krok Prezydenta spotkał się z negatywną reakcją części samorządowców i przedsiębiorców, którzy nie kryli swojego rozczarowania blokowaniem możliwości ułatwionego odrolnienia gruntów rolnych, którego nie udało się znieść jeszcze za czasów poprzedniego prezydenta (poprzednią, podobną próbę zablokował w 2008 r. Prezydent L. Kaczyński). Nowy, prezydencki projekt ustawy nowelizującej, którego wniesienie obiecał Prezydent w razie uwzględnienia jego weta, zawierał rozwiązanie kompromisowe - utrzymujące obowiązek uzyska-

Zob. Kontrowersje wokół ustawy o nasiennictwie, „Gazeta Prawna”, 22.12.2012, http://prawo.gazetaprawna.pl/ artykuly/670438,kontrowersje_wokol_ustawy_o_nasiennictwie.html (data dostępu: 21.6.2015 r.). A. Willma, O co chodzi w wojnie o GMO? O ogromne pieniądze, „Gazeta Pomorska”, 24.11.2012, http://www.pomorska.pl/apps/ pbcs.dll/article?AID=\%2F20121124\%2FREPORTAZ\%2F121129678 (data dostępu: 21.6.2015 r.); Przedstawiony przez Prezydenta Rzeczypospolitej Polskiej projekt ustawy o nasiennictwie (Sejm VII kadencji, Druk nr 176 z 5.1.2012 r.). Uzasadnienie s. 29 i nn. tów rolnych i leśnych (Sejm VII kadencji, Druk nr 3157 z 12.12.2014 r.). Uzasadnienie s. 8. 
nia zgody ministra, ale wprowadzający od tej zasady wyjątki ${ }^{27}$. Chociaż nie wiadomo czy i jaki był wpływ grup interesów na decyzję Prezydenta, można z dużym prawdopodobieństwem zakładać, że miał miejsce.

Aktywność Prezydenta dotycząca odmowy podpisania ustawy i skierowania jej do ponownego rozpatrzenia przez Sejm była niewielka i ograniczyła się do 4 przypadków. Na stronie internetowej Prezydenta można odnaleźć sugestie dotyczące zewnętrznego wpływania na jego decyzję, szczególnie w przypadku ustawy o nasiennictwie: „Jak zapewniała w piątek Kancelaria Prezydenta, prezydent analizuje argumenty różnych stron. Prezydent z najwyższą uwagę wsłuchuje się w argumenty różnych stron prezentowane w dyskusji na temat skutków prawnych wprowadzenia tej ustawy ${ }^{28} "$ - nie podano jednak ani źródeł opinii, ani ich treści, ani sugestii, które uwagi Prezydent wziął pod uwagę. Ogólnych wskazówek możemy doszukiwać się w notkach prasowych Kancelarii Prezydenta, które informują o spotkaniach z przedstawicielami środowisk naukowych, społecznych, ale także grup interesów zainteresowanych materią ustawy. $Z$ informacji wynika, że w spotkaniu wzięły udział podmioty takie jak: Instytut Spraw Obywatelskich, Stowarzyszenie Ekoland, Stowarzyszenie „Dla Ziemi”, Fundacji ICPPC, Federacji Związków Pracodawców-Dzierżawców i Właścicieli Rolnych, czy Polska Izba Nasienna. Nie wskazano jednak żadnych konkretnych postulatów, ani ich wpływu na opinię Prezydenta RP ${ }^{29}$.

Wnioski do Trybunału Konstytucyjnego również mogą być wykorzystywane przez lobbystów do wpływania na proces legislacyjny. O ile samo złożenie wniosku wymaga jedynie przekonania Prezydenta i dostarczenia argumentów natury konstytucyjnej, o tyle skuteczny wpływ na ostateczną, merytoryczną decyzję jest zagadnieniem wykraczającym poza niniejsze rozważania. Warto w tym miejscu dodać, że z takim wpływem również mamy do czynienia, a część amerykańskich ustaw lobbingowych również ten wpływ lobbystów poddaje kontroli. Wśród nielicznych ustaw, które Prezydent w czasie mijającej kadencji skierował do Trybunału Konstytucyjnego śladów wpływu zewnętrznego na jego decyzję można doszukiwać się w przypadku ustawy przewidującej zmiany w systemie otwartych funduszy emerytalnych. To wzbudzające duże kontrowersje zagadnienie było przedmiotem licznych wypowiedzi publicznych polityków i ekspertów, a także tematem obrad prezydenc-

Zob. Prezydent skierował do Sejmu projekt nowelizacji ustawy o ochronie gruntów, http://prawo.gazetaprawna. pl/artykuly/841592, prezydent-skierowal-do-sejmu-projekt-nowelizacji-ustawy-o-ochronie-gruntow.html; Sawicki o wecie Komorowskiego: Komorowski uległ PiS, http://www.gazetaprawna.pl/artykuly/813230,weto-ustawy-o -odrolnieniu-sawicki-o-wecie-komorowskiego-komorowski-ulegl-pis.html (data dostępu: 30.07.2015 r.). BCC źle ocenia weto nowelizacji ustawy o ochronie gruntów rolnych i leśnych, 25.11.2008, http://biznes.gazetaprawna. pl/artykuly/97240,bcc_zle_ocenia_weto_nowelizacji_ustawy_o_ochronie_gruntow_rolnych_i_lesnych.html (data dostępu: 21.6.2015 r.).

28 Prezydent analizuje argumenty różnych stron ws. ustawy o GMO, 12.8.2011, http://www.prezydent.pl/aktualnosci/wydarzenia/art,1907, prezydent-analizuje-argumenty-roznych-stron-ws-ustawy-o-gmo.html (data dostępu: 30.07.2015 r.).

29 Spotkanie minister Ireny Wóycickiej ws. ustawy o nasiennictwie, 19.8.2011, http://www.prezydent.pl/aktualnosci/wydarzenia/art,1915,spotkanie-minister-ireny-woycickiej-ws-ustawy-o-nasiennictwie.html (data dostępu: 30.07.2015 r.). Konsultacje prezydenta ws. ustawy o nasiennictwie, 17.8.2011, http://www.prezydent.pl/aktualnosci/wydarzenia/art,1912,konsultacje-prezydenta-ws-ustawy-o-nasiennictwie.html (data dostępu: 20.6.2015 r.). 
kiego Forum Debaty Publicznej. Prezydent podpisał ustawę, ale w trybie kontroli następczej skierował wniosek do Trybunału.

Na ponad 120 umów międzynarodowych, które podlegały ratyfikacji nie zdarzyło się, aby Prezydent odmówił ratyfikacji którejkolwiek z nich. Mógłby odmówić, nawet w przypadku wyrażenia zgody na ratyfikację przez Sejm i Senat, ponieważ zgoda jedynie otwierają drogę do ratyfikacji, ale ostateczna decyzja należy do Prezydenta. Ten obszar procesu decyzyjnego jest słabo znany. Poza głośnymi kontrowersjami wokół ACTA (proces ratyfikacyjny został zawieszony) i tzw. Konwencją antyprzemocową, czyli Konwencją o zapobieganiu i zwalczaniu przemocy wobec kobiet i przemocy domowej z 2011 r. (Prezydent ją ratyfikował, za zgodą wyrażoną w ustawie przez Sejm i Senat), do wiadomości publicznej nie dotarły informacje o wywieraniu wpływu na Prezydenta w opisanej dziedzinie. Nie wiadomo również, czy na treść któregoś z 14 rozporządzeń wykonawczych wydanych przez Prezydenta w czasie obecnej kadencji wpływali zawodowi lobbyści.

3. Wnioski końcowe $\mathrm{z}$ przeprowadzonych badań można zebrać $\mathrm{w}$ kilku punktach:

De lege lata:

- z nieznanych powodów ustawa z 7 lipca 2005 r. o działalności lobbingowej w procesie stanowienia prawa jest w zakresie dotyczącym Prezydenta jako adresata działalności lobbingowej oraz Kancelarii Prezydenta jako obsługującego go urzędu - martwa. Ustawa nakłada na administrację prezydencką kilka obowiązków, które powinny być spełnione jednorazowo (szczegółowe określenie sposobu postępowania pracowników Kancelarii z podmiotami wykonującymi zawodową działalność lobbingową oraz z podmiotami wykonującymi bez wpisu do rejestru czynności z zakresu zawodowej działalności lobbingowej) lub regularnie (informacje bieżące o kontaktach lobbingowych oraz zbiorcze coroczne zestawienia działań lobbingowych podejmowanych wobec Prezydenta i Kancelarii)

- W minionej kadencji miały miejsce przypadki konsultowania z grupami interesów zarówno decyzji dotyczących zainicjowania przez Prezydenta lub powstrzymania go od wdrażania określonych działań z zakresu tworzenia prawa, jak i wpływania na szczegółową treści projektów aktów prawnych. Zdarzenia te nie mają odzwierciedlenia w żadnych oficjalnych raportach czy zestawieniach. Szczątkowe wiadomości, zapewne jedynie o części z nich pochodzą ze skrótowych notek medialnych, informacji prasowych Kancelarii Prezydenta lub uzasadnień projektów aktów prawnych. Istnieje prawdopodobieństwo, że część z tak przeprowadzonych kontaktów z konsultowanymi podmiotami spełniała przesłanki zawodowej działalności lobbingowej. Możliwe, że wiele kontaktów w ogóle nie zostało ujawnionych z powodu nieprzestrzegania ustawy lobbingowej. 
Prezydencki lobbing. Regulacja prawna działalności lobbingowej w odniesieniu...

De lege ferenda:

- Prezydent posiada stosunkowo liczne kompetencje i uprawnienia dotyczące procesu stanowienia prawa, które czynią z niego atrakcyjny cel dla lobbystów. Wpływ wywierany na Prezydenta w tym zakresie w praktyce nie podlega w ogóle kontroli lobbingowej. Część z nich ma oryginalny charakter typowy tylko dla instytucji Prezydenta (ratyfikacja umów międzynarodowych, weto ustawodawcze, inicjowanie prewencyjnej kontroli konstytucyjności prawa).

- Polska regulacja lobbingu ,prezydenckiego” posiada te same wady i braki, które dotyczą lobbingu adresowanego do władzy ustawodawczej. Wśród nich przede wszystkim brak obowiązku składania regularnych raportów przez zawodowych lobbystów oraz zawężenie definicji lobbysty. Szczególnie druga z wymienionych wad ustawy sprawia, że łatwo jest obejść jej przepisy dotyczące statusu zawodowego lobbysty, aby nie podlegać dzięki temu w ogóle rygorom ustawy. Jest to dodatkowy powód, aby ustawę o działalności lobbingowej zastąpić nową, spójną, o możliwie szerokim zakresie podmiotowym i przedmiotowym, a przede wszystkim bardziej skuteczną pod względem realizacji założonych celów regulacji i egzekwowania jej postanowień.

- Do rodzajów aktywności lobbystów, których nie obejmuje swoim zakresem ustawa lobbingowa należą także szczególne przejawy lobbingu adresowanego do Prezydenta, przede wszystkim lobbingu pośredniego (akcje medialne i promocyjne, grass-roots lobbying, działalność stałych lub tworzonych ad hoc gremiów doradczych o charakterze eksperckim, w których składzie mogą znaleźć się lobbyści zawodowi zyskując wpływ na proces decyzyjny). Regulacja lobbingowa nie obejmuje także uprawnień Prezydenta spoza obszaru procesu ustawodawczego (uprawnienia kreacyjne - przede wszystkim dotyczące wojska, władzy sądowniczej, ministrów, prawo łaski, prawo nadawania orderów i odznaczeń, obywatelstwa). Lista postulatów de lege ferenda zgłaszanych pod adresem ustawy lobbingowej powinna ulec poszerzeniu o wskazane kwestie.

Można mieć jedynie nadzieję, że po 10 latach od wejścia w życie ustawa lobbingowa w części obejmującej działania dotyczące prezydenckiego udziału w procesie stanowienia prawa przestanie być martwa. Rozpoczęta w 2015 r. kadencja nowego prezydenta RP, trzeciego pod rządami ustawy lobbingowej, jest ku temu dobrą okazją. 


\section{BIBLIOGRAFIA}

Banaszak Bogusław. 2009. Konstytucja Rzeczypospolitej Polskiej. Komentarz. Warszawa: CH Beck.

Bielakowski Cezary. 2015. „Wojna ze szmatami”. Wprost, 13-19 kwietnia 2015: 20-21.

Kuczma Paweł (red.). 2013. Ustawa o działalności lobbingowej w procesie stanowienia prawa. Komentarz, Toruń: Towarzystwo Naukowe Organizacji i Kierownictwa.

Skrzydło Wiesław. 2000. Konstytucja Rzeczypospolitej Polskiej. Komentarz. Kraków: Zakamycze.

Spurek Sylwia. 2015. Działalność lobbingowa w procesie stanowienia prawa. Komentarz. LEX.

Winczorek Paweł. 2008. Komentarz do Konstytucji Rzeczypospolitej Polskiej z dnia 2 kwietnia 1997 roku, Warszawa: Liber.

Wiszowaty Marcin Michał. 2010. Działalność lobbingowa w procesie stanowienia prawa. Ustawa z dnia 7 lipca 2005 r. z komentarzem. Warszawa 2010: Wydawnictwo Sejmowe.

Wróblewska Iwona. 2012. „Wysłuchanie publiczne w Polsce. Analiza rozwiązań normatywnych na tle praktyki ich stosowania”. Przegląd Sejmowy 3 (110): 89-108. 
Prezydencki lobbing. Regulacja prawna działalności lobbingowej w odniesieniu...

PRESIDENT'S LOBBYING. LEGAL REGULATION OF LOBBYING ACTIVITIES IN RELATION TO THE PRESIDENT OF POLAND. THEORY AND PRACTICE.

The Polish law on lobbying activity in the legislative process was passed on July 7 th, 2005.

Analysis of the practice of the law on lobbying could lead to a conclusion that it covers only the Sejm, the Senate and the Council of Ministers' activities. Nevertheless - which is the main thesis of this article - it applies also to the president of Poland, as a head of state and important organ of the executive power.

„Professional lobbying activities” in Poland are related to specific rights and duties. These include partly lobbyists, and most of all the recipient of lobbying.

According to the law on lobbying, the head and employees of the presidentialoffice have certain responsibilities and duties. Firstly they are obliged to report all lobbying activities addressed to the president. Secondly - the head of the office should regulate in detail the inner rules of lobbying activities conducted therein. After 10 years the law on lobbying is still not applicable to the described area. There are no reports and no inner regulations at all.

This article provides justification for the thesis presented above: the Lobbying Act applies to the president and his administration. In the article I also present some examples of different types of lobbying activity addressed to the president of Poland.

The article aims to strengthen the postulate of immediate implementation of the provisions of the Act, which for the past decade was not at all respected by the presidential administration. The conclusions of the article are summarized in several points. They apply to both the current lobbying law and proposals for the necessary changes.

Keywords: president, lobbying, disclosure, interest groups, legislative process, transparency

Słowa kluczowe: Prezydent, lobbing, grupy interesu, proces legislacyjny, jawność 